\title{
"POLITIK HISTORIOGRAFI" SEJARAH LOKAL: KISAH KEMENYAN DAN KAPUR DARI BARUS, SUMATERA UTARA
}

\author{
Ichwan Azhari \\ Jurusan Sejarah, Universitas Negeri Medan
}

\begin{abstract}
Abstrak: Penelitian ini bertujuan untuk mengungkapkan posisi Barus dalam sejarah nasional dan sejarah global. Guna mendapatkan jawaban atas pertanyaan penelitian, dipergunakan metode sejarah dan kajian historiografi. Kesimpulan dari penelitian ini adalah: pertama, Barus dan komoditi kemenyan serta kamper telah dikenal oleh pasa dunia sejak lama, kedua, meskipun historiografi tentang Barus sudah selayaknya ditempatkan sebagai warisan nasional, namun lingkup historiografisnya masih sejarah lokal, ketiga, terdapat politik kekuasaan yang dapat merubah posisi Barus dalam sejarah nasional Indonesia
\end{abstract}

Kata-kata kunci: Barus, kamper, kemenyan, historiografi, lokal

\begin{abstract}
This research aims to reveal Barus's position in national history and global history. In order to get answers to research questions, historical methods and historiographic studies are used. The conclusions of this study are: firstly, Barus and commodities of incense and camphor have been known by the world pasa for a long time; second, although the historiography of Barus should be placed as a national heritage, but the historiographical sphere is still local history; third, there is political A power that can change Barus's position in Indonesia's national history.
\end{abstract}

Keywords: Barus, camphor, incense, historiography, local

Selama ini dalam pembelajaran sejarah di Indonesia, sejarah nasional dibedakan dengan sejarah lokal, yang pertama dianggap lebih penting dari yang kedua. Yang pertama adalah arus utama sejarah Indonesia, wajib dipelajari di sekolah sekolah sementara yang kedua hanya unsur tambahan pelengkap saja dari historiografi nasional dan di sekolah (seandainya pun dipelajari) hanya sebagai pelajaran muatan lokal semata. Paradigma ini bukan hanya keliru dalam menjelaskan sejarah Indonesia tapi merendahkan kecerdasan kita dalam memahami masa lalu bangsa ini.

Dalam berbagai seminar sejarah di level nasional sudah sangat sering dibahas cara pandang keliru yang memisahkan "Sejarah Nasional" dan "Sejarah Lokal" dalam pembelajaran sejarah. Definisi yang dipakai dalam merumuskan "Sejarah
Nasional" pra-kolonial maupun era kolonial juga membingungkan. Banyak tema "sejarah lokal" di Pulau Jawa (Kartini misalnya) masuk menjadi "sejarah nasional" dan membinasakan "sejarah lokal" pergerakan perempuan di tempat lain (Dewi Sartika di Jawa Barat atau Rohana Kudus di Sumatera misalnya) atau "mengurungnya menjadi sejarah lokal" yang tidak perlu dipelajari secara nasional. Perang Diponegoro yang berlangsung 5 tahun dianggap sejarah nasional sementara Perang Sunggal di Medan yang berlangsung 25 tahun dianggap sejarah lokal. Candi Borobudur dan Prambanan dibicarakan sebagai sejarah Nasional sementara kompleks Candi Padang Lawas dan Candi Kota Cina di Sumatera Utara serta kompleks candi terbesar di dunia yang ada di Muara Jambi, dianggap sejarah lokal. 
Pada era perdagangan internasional hasil hutan, rempah rempah dan tambang, berlangsung sudut pandang segelintir otoritas penulis sejarah di Jakarta untuk menentukan mana yang nasional dan mana yang tidak masuk dalam narasi nasional sehingga "ditampung saja" sebagai sejarah lokal. Sejarah rempah-rempah di Maluku yang berlangsung beberapa ratus tahun menjadi sejarah nasional sementara sejarah kemenyan dan kapur dari Barus di Sumatera Utara yang berlangsung ribuan tahun tidak digubris dan masuk kotak menjadi sejarah lokal, yang di tempat asalnya (Barus) dipelajaripun tidak. Begitu juga sejarah lada dari Sumatera yang selama ratusan tahun menjadi pemasok dua pertiga kebutuhan lada di dunia, yang dialirkan lewat pelabuhan pelabuhan di pantai timur dan barat Sumatera, hilang dalam pelajaran sejarah nasional Republik Indonesia.

Uraian berikut memperlihatkan kisah tentang Barus, "sejarah lokal" yang tidak dibicarakan dalam "sejarah nasional", padahal sejarah yang dikandungnya sudah masuk dalam sejarah dunia, situs, artefak peninggalanya serta catatan sumber sejarah yang menyertainya memperlihatkan Barus merupakan satu dari sedikit kota kuno yang penting dalam sejarah dunia. Saking pentingnya dua komoditi ini dalam peradaban Timur Tengah bahkan ketika Jesus lahir Bibel menyebut kemenyan salah satu yang dipersembahkan dan kapur Barus masuk dalam Al Quran. Kawasan tempat diperdagangkannya dua komoditi utama dunia selama lebih dari dua ribu tahun yakni kemenyan dan kapur (kamfer), kini merupakan hanya satu kota kecil yang lesu dan tidak begitu berarti. Jika kita buka semua buku IPS dan sejarah siswa di Barus dari SD sampai SMA bisa dipastikan sejarah Barus tidak ditemukan. Barus tidak masuk dalam pelajaran sejarah nasional untuk itu silakan masuk kotak sejarah lokal yang kapan perlunya saja dibicarakan saat tidak menganggu waktu untuk pelajaran sejarah nasional yang jauh dari Barus.

\section{BARUS DALAM SUMBER-SUMBER INTERNASIONAL}

Di antara banyaknya jenis komoditi dagang internasional, terdapat dua jenis komoditas hasil hutan khas Nusantara yang memiliki daya pikat tinggi, sangat dicari, dan bahkan harganya hampir disetarakan dengan emas. Komoditas tersebut adalah kapur barus dan kemenyan yang banyak tumbuh di hutan-hutan Sumatera bagian utara. Keberadaan kapur barus (kamper) kawasan ini kemungkinan besar yang belakangan menjadi latar belakang penamaan salah satu bandar dagang penting di Pantai Barat Sumatera yaitu Barus. Tempat ini bahkan telah diberitakan oleh Claudius Ptolemaeus pada abad ke-2 M dalam bukunya Geographyke Hyphegeiss yang menyebut Barus sebagai Barousai (Ambary, 1998:57).

Besarnya animo pedagang asing pada masa lalu terhadap perdagangan kapur barus dan kemenyan juga terbukti dari keberadaan Prasasti Tamil yang ditemukan di Desa Lobu Tua, Kec. Andam Dewi, pada tahun 1873 oleh kontrolir Belanda di Barus bernama Dr. J. Brandes. Berdasarkan analisis epigrafi yang dilakukan oleh Y. Subbrayalu disebutkan bahwa prasasti itu adalah prasasti dari perkumpulan pedagang Tamil yang bermukim di Lobu Tua bernama "Yang Ke Lima Ratus Dari Seribu Arah" dengan tarikh 1010 Saka atau 1008 M (Guillot, 2002:22). Meskipun di dalam prasasti tersebut tidak disebutkan jenis komoditas dagang seperti kapur barus maupun kemenyan, akan tetapi prasasti itu dapat menjadi bukti keberadaan kelompok pedagang Tamil yang mendiami Lobu Tua hampir tiga abad untuk mendapatkan kapur barus dan kemenyan dari sumbernya langsung. 
Pentingnya kapur barus dan kemenyan sebagai komoditas dagang juga dapat ditelusuri melalui catatan dan laporan perjalanan yang ditulis oleh pedagang-pedagang asing seperti bangsa Armenia, Tamil, Arab, Persia, China, Melayu, Jawa dan Eropa. Selain itu historiografi mengenai kapur barus dan kemenyan juga telah diteliti, ditulis, dan diterbitkan oleh para peneliti dalam skala internasional. Catatan dan laporan perjalanan bangsa-bangsa asing tersebut serta berbagai karya tulis yang dihasilkan oleh para peneliti mengenai kapur barus dan kemenyan merupakan literatur penting yang harus diulas untuk mengkaji kapur barus dan kemenyan sebagai komoditas dagang penting pada masa lalu.

Keberadaan kapur barus dan kemenyan sebagai salah satu komoditi dagang cukup berpengaruh terhadap eksistensi dan berkembangnya bandar-bandar pelabuhan yang ada di Pulau Sumatera. Di Barus misalnya, perdagangan kapur barus dan kemenyan menjadi salah satu indikator maju dan mundurnya pelabuhan di kawasan tersebut. Sumber-sumber tertulis asing juga sering kali menginformasikan mengenai perdagangan kapur barus dan kemenyan yang banyak diambil dari hutan-hutan di Sumatera. Oleh sebab itu untuk menelisik seberapa besar peran kapur barus dan kemenyan dalam diaspora perdagangan Nusantara abad ke-7 sampai abad ke-20 M maka tidak dapat dilepaskan dari keberadaan sumber-sumber asing tersebut. Sumber-sumber sejarah itu menjadi salah satu literatur utama dan pijakan awal untuk mengkaji historiografi kapur barus dan kemenyan dalam perdagangan internasional kuno hingga modern di Nusantara. Sumbersumber tertulis asing yang dimaksud adalah berasal dari sumber Arab, Persia, Armenia, Tamil, China dan Eropa.

Lokasi sumber kapur barus yang paling sering disebut dalam sumber-sumber asing adalah tempat bernama Fansur. Akan tetapi terdapat perbedaan pendapat dari beberapa ahli mengenai di mana lokasi bernama Fansur itu saat ini. E. Edward McKinnon berpendapat bahwa Fansur terletak di ujung barat Aceh dengan nama Teluk Pancu. Hipotesis tersebut diperkuat dengan pertimbangan letak geografis dan data dari berbagai sumber sejarah seperti sumber Armenia abad ke-12 M, Arab yang ditulis oleh Sulaiman al-Mahri pada abad ke-17 M, sumber dan peta-peta Eropa yang menyebut nama Panchu di bagian barat Aceh dari abad ke-18 sampai ke-19 M (McKinnon, 2016). Uraian McKinnon ini memberi dimensi baru tentang Fanchu yang menurutnya ada di Utara Aceh dan bukan di Pantai Barat Sumatera Utara. Bisa jadi menurut Mckinnon dengan kapal kecil Kapur dari Barus itu dibawa ke Pancu dan dari Pancu di perdagangkan ke dunia internasional.

Kéram Kévonian berpendapat letak lokasi Fansur yang banyak disebut dalam sumber-sumber asing saat ini belum jelas. Dia mengusulkan tiga lokasi yang kemungkinan dimaksud dengan Fansur yaitu Barus, sebuah kota di Semenanjung Malaya dan seluruh kawasan pantai barat Sumatera (Barus) - bagian utara pantai timur Sumatera. Pendapatnya itu didasarkan pada sumber Arab yang ditulis oleh Sulayman al-Mahri dan Ibn Khordadbih, sumber Armenia dan sumber Eropa (Kevonian, 2002). Selain itu Roderich Ptak berpendapat bahwa Fansur terletak di Barus. Sumber sejarah dan petapeta China dari Dinasti Ming seperti Peta Mao Kun, dokumen resmi Ming Shilu, laporan ekspedisi Zheng He dan buku sejarah Ming Shi dinilai menggambarkan Fansur/ Fansu'er/Pancur terletak di Pantai Barat Sumatera yakni Barus (Ptak, 2002).

\section{Sumber Arab}

a. Sebuah tulisan berjudul Ahbār aş-şīn wa l-hind atau Catatan Mengenai Cina dan India yang ditulis pada tahun $851 \mathrm{M}$. Tu- 
lisan ini merupakan catatan terawal dalam sumber tertulis Arab mengenai daerah Fansur sebagai penghasil kamper bermutu tinggi. Namun sayangnya penulis naskah ini tidak diketahui. Dalam sumber ini dituliskan:

"Katanya pulau ini seluas 800 atau 900 parasanges (persegi). Pulau ini mengandung banyak emas dan sebuah tempat yang bernama Fantsour menghasilkan kamper bermutu tinggi”. (Stephan, 2002: 215).

b. Sebuah kitab berjudul Kitāb al-masālik wa-l-mamālik atau Buku Tentang JalanJalan dan Kerajaan-Kerajaan yang ditulis oleh Ibn Khordadhbeh pada tahun 850 M di Samarra (Irak). Dalam kitab ini dituliskan:

"Di antara Pulau Langabalūs dan

Pulau Kilah, terdapat Pulau Bālūs yang dihuni oleh manusia kanibal. Pulau ini menghasilkan kamper yang bermutu tinggi, pisang, kelapa, tebu dan beras". (Ferranda, 1913-1914 dalam Stephan, 2002: 217)

c. Sebuah kamus berjudul Lisān al-'arab yang ditulis oleh salah seorang ahli tata bahasa dari Mesir, Ibn Manzur, yang ditulis kira-kira pada akhir abad ke-13 M. Ibn Manzur berpendapat bahwa istilah kāfür selain berarti kamper, juga dipakai untuk suatu ramuan bumbu yang diperoleh dari kāfūr al-tal' (sejenis daun dari pohon palem) dan juga kāfür alkarm (sejenis daun dari pohon anggur) (Lane, 1863-1893, dalam Stephan, 2002: 218).

d. Sebuah naskah sejarah karya sejarawan Ibn al-Atīr (meninggal tahun $1233 \mathrm{M}$ ) dan Ibn al-Balādūrī (meninggal tahun $1473 \mathrm{M}$ ) tercatat bahwa pada tahun 16 H/637 M, sewaktu perebutan ibu kota Dinasti Sassanid, yaitu Ctesiphon, penakluk-penakluk Arab menemukan kamper - yang semula dikira garam - di antara rempah-rempah dan wangi-wangian hasil rampasan. Jika cerita ini benar, maka dapat dikatakan bahwa kamper sebagai komoditi yang dihasilkan pohon kapur sudah dikenal pada awal zaman berkembangnya agama Islam (Raynaud, 1967: 590 dalam Stéphan, 2002: 218).

e. Sebuah naskah berjudul Atār al-bilāh wa ahbār al-ibād atau Buku Monumen, Negeri, dan Informasi Tentang Manusia yang ditulis ahli geografi bernama alQazwīnī (meninggal tahun 1283 M). Dalam naskah ini dituliskan:

"Di selatan, di bagian barat daya pulau ini terletak Kota Fancur yang namanya diberikan kepada kamper yang disebut Fancuri" (Stephan, 2002: 220).

f. Sebuah informasi tentang Pulau Sumatera yang diberikan oleh Ahmad b. Māğid al-Nağd dari Oman, yaitu : "Di sana terdapat gajah putih, kamper, bunga pala dan kasturi, yang hanya dibeli dengan emas. Semua pemimpinnya adalah orang kafir." (Stephan, 2002: 220).

g. Sebuah naskah berjudul Nuhbat al-dahr fi a'gā'ib al-barr wa-l-bahr atau Beberapa Kejadian di Darat dan di Laut karya seorang ahli geografi bernama alDimaškī (meningal tahun $1325 \mathrm{M}$ ) menuliskan bahwa Fansur menghasilkan kamper yang terbaik. Selain memuat deskripsi rinci tentang cara mengambil kamper, dicatat pula bahwa kamper terbaik adalah ribahi dan fançuri yang hanya dijumpai di bagian puncak pohon atau dahan-dahan yang warnanya merah mengkilat (Ferrand, 1913-1914 dalam Stéphan, 2002: 220).

h. Sebuah naskah yang ditulis oleh Ibn Khordadhbeh mengenai deskripsi pohon kamper yang ada di Pegunungan Djawaga. Ia menuliskan: 
"Di kawasan ini terdapat pohon kamper yang besar sekali sehingga daun-daunnya bisa membayangi sekitar 100 orang. Untuk memperoleh kamper, puncak pohonnya ditoreh dan air kamper yang keluar banyak, sehingga dapat mengisi beberapa tempayan. Sesudah airnya dikutip, bagian tengah batangnya ditoreh untuk mendapat potongan-potongan kamper, bahan ini merupakan gom dari pohonnya sendiri” (Stephan, 2002: 220).

i. Sebuah naskah berjudul Tuhfat alNuzzhar fi Ghara'ib al-Amshar wa 'Aja'ib al-Asfar atau Persembahan Seorang Pengamat Tentang Kota-kota Asing dan Perjalanan yang Mengagumkan ditulis oleh Ibn Battuta. Dalam tulisannya ia menjelaskan bahwa:

"Pohon-pohon yang mengandung kamper adalah sejenis buluh yang serupa dengan tanaman air di kawasan kita; perbedaannya adalah bagian di antara dua bonjol lebih panjang dan tebal. Ketika batangnya dipotong tangkai yang mengandung kamper kelihatan" (Stephan, 2002:222).

Dalam laporan perjalanan Ibn Battuta ini juga mencatat keberadaan kemenyan ketika singgah di pantai utara Sumatera tahun 1346 dengan nama Luban Jawi dan memberikan deskripsi pohonnya (Katz, 2002:252). Ia juga mencatat bahwa kamper merupakan produk yang diekspor melalui Pasai (Perret, 2015:605).

j. Kumpulan arsip Geneiza dari Kairo yang tahun 1080 - 1240 banyak mencatat kamper dari Fansur sebagai produk dagang. Sebuah surat yang dikirim dari Aden pada tahun 1180 dan ditujukan kepada seorang pedagang di Timur Jauh mencatat harga kamper dari Fansuri. Selain itu kamper dari Fansuri juga ditulis sebagai produk kamper dengan kualitas yang baik yang diimpor utama ke Benggala sejak abad ke-12 M (Drakard, 1989, dalam Perret, 2015: 604).

\section{Sumber Persia}

a. Sebuah buku berjudul Akbarnameh atau Buku Akbar yang ditulis oleh Abū alFazl (meninggal tahun 1602) yang berisikan:

"Kamper diperoleh dari batang dan dahan. Kamper yang ada di dalam kayu serupa dengan butiran kecil garam; kamper yang ada di luar kayu serupa getah dan mengeras beberapa lama sesudah mengalir ke tanah. Di antara jenis kamper yang terbaik adalah ribāhī atau Fancūrī. Walaupun namanya berbeda tetapi jenisnya sama. Katanya kamper ditemui untuk pertama kalinya oleh seorang raja yang bernama Ribah, dekat Fancur, sebuah tempat dengan Pulau Sanadib" (Stephan, 2002: 227).

b. Sebuah buku ilmu kedokteran berjudul Buku Tentang Sifat Obat-Obatan Asli yang ditulis oleh Ibn Sarabiyu pada abad ke-10 M, menuliskan:

"Kamper bermutu tinggi dinamakan al-riyahi, kamper ini adalah suatu bahan alami. Warnanya merah berbintik-bintik tetapi menjadi putih sesudah disublimasi di tempat asalnya. Tempat asalnya bernama Fansur dan dari nama ini berasal nama sejenis kamper, yaitu fansuri. Kamper ini adalah jenis terbaik, paling ringan, palling murni, paling putih, dan paling mengkilat. Potonganpotongan terbesar sebesar kirakira mata uang dirham" (Stephan, 2002:228).

\section{Sumber Armenia}

a. Sebuah naskah geografi berbahasa Armenia berjudul "Nama Kota-Kota Di India dan Kawasan Pinggiran Persia Versi (F) Matenadaran no. 5950, h.198 r ${ }^{\circ}-$ $202 \mathrm{r}^{\mathrm{o}}$ abad ke-8 M" mendeskripsikan 
lokasi-lokasi yang pernah dikunjungi oleh para ahli geografi. Masa terawal naskah ini besar kemungkinan berasal dari abad ke-11 sampai abad ke-13 $\mathrm{M}$, baru setelah itu banyak disunting dalam berbagai edisi. Dalam naskah ini dituliskan:

"Negeri Bumi Emas dinamakan Reminzar, karena menghasilkan emas sebanyak yang diinginkan. Nama-nama kota di Bumi Emas adalah sebagai berikut. Kota pertama dan pelabuhan pertama: Lambrē. Di tempat ini banyak terdapat kayu sepang dan bahan berharga lainnya; apa saja yang diinginkan terdapat di pelabuhan ini. Dari sini orang berangkat untuk pergi ke Pant'chour, sebuah kota dan pelabuhan pedagangan yang ramai sekali, yang mengeluarkan kamper bermutu" (Kevonian, 2002:31-32).

b. Naskah geografi berbahasa Armenia berjudul Armenia berjudul "Nama KotaKota Di India dan Kawasan Pinggiran Persia Versi Ams., C, D, E, Ven., G Edisi Asal Amsterdam 1668" menyebutkan hanya dua pelabuhan yang menjual kamper bermutu yaitu P'anes atau P'anis atau Panai atau Pane di Pantai Timur (Selat Malaka) dan Pant'chour atau Barus di pantai Barat (Samudra Hindia) (Kevonian, 2002:72).

c. Sebuah buku ilmu kedokteran berbahasa Armenia berjudul Mechitar's des Meisterarztes aus Her "Trost bei Fiebern yang ditulis oleh Mechitar tahun 1184 menyebutkan bahwa kamper adalah salah satu jenis obat yang dipakai untuk demam. Dalam buku ini dituliskan:

"Untuk menguatkan jantung, letakkan bahan-bahan pengharum dalam rumah; mengolesi dinding dengan campuran kamper, cendana dan air mawar; menyiraminya di seluruh rumah supaya se- merbak ahrup. Efeknya sudah terbukti. Kemudian larutkan kamper dalam air, rendam kain lenen di dalamnya sebelum ditaruh di atas dada dan jantung" (Stephan, 2002:232)

\section{Sumber Tamil}

Sampai sejauh ini, sumber tertulis beraksara tamil yang berkaitan dengan perdagangan kapur barus maupun kemenyan yang diketahui adalah prasasti perkumpulan pedagang Tamil bernama "Yang Ke Lima Ratus dari Seribu Arah" dengan tarikh $1088 \mathrm{M}$ yang ditemukan di Lobu Tua pada tahun 1873 oleh kontrolir Belanda di Barus, Dr. J. Brandes. Meskipun dalam prasasti tersebut tidak dituliskan kapur barus dan kemenyan sebagai komoditi dagang kelompok pedagang tersebut, namun terdapat penjelasan bahwa:

"Kapten kapal dan para kevi harus membayar biaya Ancut-tunt-ayam dalam bentuk emas menurut harga kasturi dan (kemudian) baru bisa menginjak kain yang dibentangkan" (Subbarayalu, 2002:20).

Kasturi yang dimaksud dalam prasasti itu merupakan jenis komoditi wewangian yang cukup terkenal, sama halnya dengan kapur barus yang juga dikenal sebagai jenis komoditi alami yang juga digunakan sebagai bahan wewangian. Oleh sebab itu, tentu keberadaan prasasti ini berkaitan dengan perdagangan kapur barus dan kemenyan yang banyak tumbuh di hutan dataran tinggi Pak Pak dan Tapanuli.

\section{Sumber China}

a. Kronik dari Dinasti Liang menyebutkan kamper dengan istilah polu xiang yang berasal dari Funan dan Langyaxiu. Kemungkinan besar, Langyaxiu terletak di Semenanjung Malaya. Jenis kamper yang ada di Langyaxiu sejenis dengan kamper yang tumbuh di Borneo dan Barus yaitu jenis Dryobalanops Aromatica (Ptak, 2002:123). 
b. Biksu I-Tsing dalam catatannya yang dibuat menjelang akhir abad ketujuh menyebut kapur barus sebagai salah satu produk andalan Shih-li-fo-shih (Sriwijaya).

c. Sebuah teks yang ditulis oleh Xintang Shu pada pertengahan abad ke-11 M menggambarkan Sriwijaya dibagi menjadi dua kerajaan yang mempunyai pemerintahan sendiri dan yang paling barat disebut Lang-po-lo-si yang menghasilkan banyak emas, air raksa, dan kamper (Wolters, 1967, dalam Perret, 2008:36)

d. Sebuah teks yang ditulis oleh Zhao Rugua berjudul Zhufan zhi pada awal abad ke-13 M mencatat bahwa terdapat dua tempat penghasil kamper yaitu Po'ni (Brunei) dan Pin-Su (Fansur) (Hirt \& Rochill, 1966, dalam Perret, 2008:59). Dalam tulisannya Zhao Rugua juga mencatat terdapat tujuh istilah yang berbeda untuk berbagai bentuk dan mutu kamper (Ptak, 1998, dalam Perret, 2015:605).

e. Chau Jukua yang menulis Chu-fan-chi (negeri-negeri barbar/asing di Laut Selatan) pada abad ke-13 menyebut bahwa kamper berasal dari P'o-ni (Kalimantan) dan Pin-su (Barus).

f. Sebuah teks berjudul Hsing-ch'a sheng lan yang ditulis pada tahun 1435 mencatat bahwa A-lu (Aru) terdapat suplai kamper yang dipanen di kawasan pegunungan (Rochill, 1915, dalam Perret, 2015:605).

g. Sumber-sumber Tionghoa dari abad ke$15 \mathrm{M}$ mencatat bahwa di utara Teluk Aru, penduduk Tan-Chiang (Tamiang) memerik kamper di hutan (Groeneveltd, 1880, dalam Perret, 2015:605). TsengHsin Chang menambahkan bahwa sejak akhir abad ke-16 M kamper dari Barus tersedia di Patani (Perret, 2008:250).

h. Sebuah tulisan karya Duan Chengsi menyebutkan kamper dengan nama gubu polu-kapur barus. Dalam tulisannya, Duan Chengsi mendeskripsikan topologi pohon kamper serta cara memperolehnya. Ia menuliskan:

"Pohonnya setinggi 80 hingga 90

kaki dan lingkarannya bisa mencapai enam atau tujuh jengkal. Daunnya bulat dengan sisi belakang hitam; tidak ada bunga atau buah. Pohonnya "gemuk" atau "kurus", yang kurus menghasilkan "minyak wangi polu" (polu gau xiang); ada juga yang mengatakan bahwa yang kurus menghasilkan "minyak wangi otak naga" (longnao xiang), sedangkan yang gemuk menghasilkan "minyak polu". (Minyak wangi otak naga) terdapat di tengah kayu. (Kamper) diperoleh setelah pohonnya ditebang dan (kayunya) dibelah. Salepnya (gao) keluar dari bagian ujung pohon; mereka memotongmotong pohonnya dan membuat lubang untuk mendapatkan salepnya" (Pellito, 1985, dalam Ptak, 2002:123)

i. Sumber dari Dinasti Tang menyebut kamper dengan istilah jiebuluo xiang, sedangkan pada sumber Dinasti Han menyebut kamper dengan istilah shi ji dan han shu, meski interpretasinya kurang meyakinkan (Pellito, 1973, dalam Ptak, 2002:123).

j. Sebuah tulisan karya Sui Shu menyebutkan kamper dengan istilah longnao xiang yakni bahan-bahan yang diberikan oleh Chitu kepada cina sebagai upeti (Wolters, 1967, dalam Ptak, 2002:123).

k. Sebuah tulisan karya Li Shizhen berjudul Bencao gangmu yang memberi gambaran terperinci tentang cara longnao xiang digunakan dalam pengobatan tradisional Cina semasa Dinasti Tang dan sesudahnya. Li Shizhen mencatat bahwa kapur barus digunakan sebagai obat sakit gigi, sakit kepala, dan saki lainnya. Kayu kapur barus juga 
digunakan sebagai bahan ukiran (Ptak, 2002:124).

1. Sebuah ulasan yang merujuk aktivitas impor-ekspor pada Dinasti Song dan Yuan yang dibuat oleh Dade Nanhai zhi yang mencatat kamper sebagai barang impor dari Kanton. Wang Dayuan juga menyebutkan kamper dan berbahan kamper berkaitan dengan Xialaiwu (Kepulauan Karimur Jawa atau Klabat), Danmaling (Ligor atau tempat lain), Pahang, Terengganu, Suluoge (Mungkin Keddah), Xuwendala (Samudra), Dudu'an (bagian barat laut Borneo), Borneo, Sriwijaya dan tempat-tempat lain, tetapi tanpa hubungan dengan Banzu dan Luoposi (Chen Dazhen, 1986, dalam Ptak, 2002:125).

m. Dalam laporan ekspedisi laut yang dilakukan oleh Laksamada Zheng $\mathrm{He}$ (Cheng Ho) disebutkan bahwa ia bersama armadanya pernah tiga kali mengunjungi Aru (Haru) yakni pada tahun 1413-1415, 1421-1422 dan 14311433. Zheng He melaporkan:

"Apabila berlayar dari Malaka, Kapal akan tiba di kerajaan Aru, setelah berlayar 4 hari 4 malam dibawah angin buritan. Disitu terdapat sebuah pelabuhan yang berair tawar. Di sebelah barat kerajaan ini berbatas dengan Kerajaan Pasai. Di sebelah selatan dan utara terdapat gunung yang tinggi dan luas. Bagian timur merupakan tanah datar yang dipakai orang Aru sebagai ladang untuk menanam padi. Berasnya kecil dan halus, hasil buminya yang utama adalah kemenyan" (Groeneveltd, 2009).

n. Sumber China yang ditulis pada abad ke-19 M yang dirangkum oleh TsengHsing Chang menjelaskan bahwa pada pertengahan abad ke-19 M terdapat tiga kategori kamper di Barus (superior: kuburan betsi; sedang: kuburan selang benah; rendah: kuburan bubuk), lima di Singkil (1: kapur becis, 2: Bakoh dahon, 3: boekboek, 4: umbutumbut, 5: gerigis), dan tiga di Air Bangis (superios: cappala, sedang: awak, rendah : kaki) (Asnan, 2007:209).

\section{Sumber Eropa}

a. Dalam sebuah tulisan menyebut bahwa Marco Polo yang mengunjungi Sumatera tahun 1291 memberikan penilaian terhadap kapur barus dari Fansur yang dianggap sebagai kapur barus terbaik di dunia yang nilainya sama dengan harga emas murni (Hambis, 1955, dalam Perret, 2010:89).

b. Sebuah laporan Eropa terawal tentang kemenyan yang ditulis oleh Diogo Pacheco seorang berkebangsaan Portugis mencatat pada abad ke-16 $\mathrm{M}$ bahwa kemenyan terbaik berasal dari Barus dengan nama kemenyan boninas (Barros, 1998, dalam Perret, 2015:610).

c. Laporan perjalanan Tome Pires berjudul Suma Oriental yang mulai ditulis tahun 1511 ketika ia berada di Malaka. Dalam tulisannya pada Fol. 163v yang berjudul Barang-Barang Dagangan yang Diproduksi di Sumatra menceritakan bahwa Sumatra menghasilkan emas dalam jumlah yang sangat besar, dua jenis kamper yang bisa dimakan, merica, sutra, kapur barus, tanaman obat lignaloe, madu, lilin, tar, belerang, kapas, dan kayu rotan (Cortesao, 2016:181).

Selain itu Tome Pires mencatat lebih detail komoditi dagang dari setiap kerajaan seperti: 1) Kerajaan Pasai yang disebut memperdagangkan merica, sutra dan kemenyan; 2) Kerajaan Batak memperdagangkan beras, anggur, buahbuahan, madu, lilin, rotan dan sedikit kamper yang bisa dimakan; 3) Kerajaan Aru memperdagangkan kamper yang 
bisa dimakan dan berkualitas, emas, kemenyan dalam jumlah besar dan berkualitas, tanaman obat lignaloe, rotan, ter, lilin, madu dan budak (laki-laki dan perempuan); 4) Negeri Palembang memperdagangkan beras, budak, kapas, rotan, emas, gerabah, ter, lilin, besi, madu, anggur, daging, bawang merah, bawang putih, dan kemenyan hitam; 5) Kerajaan Barus disebut selalu didatangi dua atau tiga kapal Gujarat setiap tahunnya untuk membeli emas, sutra, kemenyan, lignaloe, dua jenis kamper jenis yang bisa dimakan dengan jumlah lebih banyak, kemenyan, obat lignaloe, lilin dan madu; 6) Kerajaan Singkel memperdagangkan sejumlah kemenyan, sutra, merica, dan emas; 7) Kerajaan Moelaboh memperdagangkan sutra, kemenyan, dan barang-barang lainnya (Cortesao, 2016:188-215).

Dalam laporan perjalanannya pula, Tome Pires mencatat bahwa salah satu jenis barang dagang yang dibawa dari Kalimantan (Borneo) ke Malaka adalah kamper yang sangat bernilai yang dibawa sebanyak 2 atau 3 bahar (Cortesao, 2016:176). Tome Pires juga mencatat para pedagang asal Kairo, Aden dan Mekkah juga membeli kemenyan yang telah dibawa ke Malaka, selain itu para pedagang asal Malabar disebut membeli kapur baru dari Fansur yang terletak di wilayah barat daya meskipun disebut nilainya tidak terlalu bernilai (Cortesao, 2016: 345-349). Disebut pula para pedagang dari Benggala juga membeli kamper dalam jumlah yang besar dari Kalimantan (dan kemungkinan dari Sumatera juga) yang dijual di Malaka (Cortesao, 2016).

d. Dalam laporan yang ditulis oleh Mandes Pinto mengenai pengalamannya berada di Malaka dan Kerajaan Bata (di sebelah utara Barus) tahun 1539 menyebutkan jenis komoditi dagang yang dijual oleh Kerajaan Bata yaitu emas, cabai, kapur barus, kemenyan dan kayu gaharu (Pinto, 1645, dalam Perret, 2010: 89-90).

e. Pada buku yang ditulis oleh William Marsden berjudul History of Sumatra yang terbit tahun 1783 memuat tulisan mengenai kapur barus dan kemenyan. Marsden menyebutkan di antara komoditas berharga di Pulau Sumatera, kapur barus dan kemenyan termasuk bahan yang sangat penting. Marsden juga menyebutkan bahwa kapur barus tidak hanya digunakan sebagai obat oleh orang Sumatra namun juga orang Borneo. Harga jual kapur barus pada waktu itu diperkirakan sebesar 6 dolar Spanyol atau 8 dolar per 500 gram dengan jumlah penjualan pertahun lebih dari 50 pekul yang dijual oleh orang Achin dari Singkel dan orang Batta. Untuk komoditi kemenyan, Marsden menjelaskan bahwa kemenyan yang telah diolah dikirim ke Inggris yang digunakan sebagai dupa di tempat-tempat ibadah dan sebagai obat (Marsden, 2013:171-177).

f. Sebuah laporan yang ditulis oleh ahli geologi Jerman, Franz Wilhelm Junghuhn, dalam tulisan Die Battalandern auf Sumatra mencatat jumlah kamper di Barus pada pertengahan abad ke-19 M diperkirakan perolehan bongkahan untuk sebuah pohon kapur barus bervariasi dari seperempat paun ke 100 kati (Junghuhn, 1847).

g. Laporan salah seorang pedagang asal Belanda bernama Radermacher menyebutkan bahwa pada akhir abad ke$18 \mathrm{M}$ pedagang dan orang-orang kaya di pedalaman Barus meletakkan kamper di dalam keranda pembesar dan orang kaya (Perret, 2015:603).

h. Sejumlah arsip Belanda yang telah diidentifikasi oleh Asnan (2007: 207211) mengenai perdagangan kamper 
dan kemenyan cukup banyak, antara lain:

1. Tulisan Stuers berjudul Bijdrage tot de Geschiedenis van Sumatra's Wesrkust: Verslag over Padang en Onderhohorigheden Opgemaakt in 1826 yang diterbitkan tahun 1908 menyebutkan pelabuhan-pelabuhan di kawasan seperti Air Bangis, Natal, Tapanuli, Barus dan Singkel selalu mencatat kapur barus dan kemenyan sebagai komoditas ekspornya. Selanjutnya Stuers juga mencatat sampai pertengahan abad ke-19 M dilaporkan bahwa jual beli kapur barus dan kemenyan antara penduduk dan pedagang asing masih dilakukan dengan cara barter. Menurut catatan Stuers tersebut pada tahun 1830 di daerah pantai harga satu pikul kapur barus kualitas campur berkisar antara $10-30$ Spaanche matten, dan pada tahun 1840 satu pikul kamper antara f.4000 - f.5000, dimana dari masing-masing pelabuhan di kawasan pantai barat bagian utara Sumatera setiap tahunya kamper diekspor sebanyak 20 pikul. Sedangkan untuk kemenyan, Stuers mencatat pada tahun 1940 harga rata-rata satu pikul kemenyan antara f.50 f.70.

2. Vriese dalam tulisannya tahun 1851 mencatat di kota-kota pantai kebanyakan kapur barus dan kemenyan dibeli oleh saudagar China. Selain itu kedua komoditas dagang ini terutama jenis dengan kualitas terbaik banyak diekspor ke Eropa (Nederland), Mekkah, Ceilo dan India (Coromandel, Surate dan Malabar).

3. De Buy dalam laporan berjudul Twee Jaren op Sumatra's Westkust memeberikan catatan mengenai kunjungannya ke Barus pada pertengahan abad ke-19 M. Ia mencatat penjualan salah seorang saudagar Cina di Barus yang bisa mencapai menjual ratusan peti kapur barus dan kemenyan ke Singapura atau ke Pulau Penang.

4. Dalam laporan A.V. Michiels berjudul De Toestand van Sumatra's Westkuts in 1848 memberikan catatn mengenai jumlah dan nilai ekspor kapur barus dan kemenyan di Pantai Barat Sumatera yaitu: 1) ekspor kapur barus tahun 1820-1829 sebanyak 4.336 peti dengan harga f.133.387 dan tahun 1830-1845 sebanyak 6.058 peti dengan harga f.196.541 dan 2) ekspor kemenyan tahun 1820-1829 sebanyak 578.000 pond dengan harga f.318.938 dan tahun 1930-1845 sebanyak 2.472.000 pond dengan harga f.753.541.

\section{KAPUR BARUS DAN KEMENYAN DALAM TULISAN-TULISAN SE- JARAH}

Menelusuri dan memahami arti penting kapur barus dalam kelompok komoditas dagang khas Nusantara tidak hanya dapat merujuk pada sumber-sumber asing telah disebutkan di atas. Saat ini telah banyak buku-buku sejarah mengenai historiografi pelayaran dan perdagangan maritim Nusantara yang mengulas lebih luas tentang kapur barus dan kemenyan. Buku-buku tersebut sangat penting untuk menjadi rujukan dalam melakukan penelitian terkait peran berbagai komoditi perdagangan terutama kapur barus dan kemenyan dalam diaspora sejarah perdagangan kuno hingga modern. Bukubuku ini ditulis oleh para peneliti dari dalam negeri maupun luar negeri yang telah diterbitkan sehingga menjadi mudah untuk di- 
akses umum. Di bawah ini akan diidentifikasikan beberapa artikel/tulisan dan buku- buku sejarah yang dapat menjadi bahan literatur dalam penelitian terkait kapur barus dan kemenyan.

\begin{tabular}{|c|c|c|c|}
\hline No & Tahun & Penulis & Judul Tulisan / Buku \\
\hline 1 & 1866 & Duarte Barbosa & $\begin{array}{l}\text { A Description of the coast of East Africa and Malabar in the beginning of the } \\
16^{\text {th }} \text { century }\end{array}$ \\
\hline 2 & 1967 & O.W. Wolters & Early Indonesian Commerce. A Study of the Origin of Srivijaya \\
\hline 3 & 1979 & $\begin{array}{l}\text { John Norman } \\
\text { Miksic }\end{array}$ & Archaeology, Trade, and Society in Northeast Sumatra \\
\hline 4 & 1984 & $\begin{array}{l}\text { Edmun Edward } \\
\text { McKinnon }\end{array}$ & $\begin{array}{l}\text { Kota Cina : Its Context and Meaning in the Trade of Southeast Asia in the } \\
\text { Twelfth to Fourteen Centuries }\end{array}$ \\
\hline 5 & 1988 & $\begin{array}{l}\text { Edmun Edward } \\
\text { McKinnon }\end{array}$ & Beyond Serandib : a note on Lambri at the northern tip of Aceh \\
\hline 6 & $\begin{array}{l}2011 / \\
2016\end{array}$ & $\begin{array}{l}\text { Mckinnon, } \\
\text { Edwards E. }\end{array}$ & $\begin{array}{l}\text { Ancient Fansur, Aceh's 'Atlantis'? The case for Lhok Pancu / Indrapurwa. } \\
\text { (revised text of IAHA Solo } 2011 \text { with addenda \& } \\
\text { corrigenda 2016) }\end{array}$ \\
\hline 7 & 1989 & $\begin{array}{l}\text { Lukman Nurha- } \\
\text { kim }\end{array}$ & $\begin{array}{l}\text { La Ville de Barus, Etude Archaelogique Preliminaire (Kota Barus : Tinjauan } \\
\text { Awal Arkeologi) }\end{array}$ \\
\hline 8 & 1989 & Jane Drakard & An Indian Ocean Port : Sources for the Early History of Barus \\
\hline 9 & 1997 & $\begin{array}{l}\text { Marina } \\
\text { Goloubinuff }\end{array}$ & $\begin{array}{l}\text { Commerce et usages du benjoin et du campher en France (Perdagangan dan } \\
\text { penggunaan kemenyan dan kamper di Prancis) }\end{array}$ \\
\hline 10 & 2002 & $\begin{array}{l}\text { Claude Guillot, } \\
\text { dkk }\end{array}$ & Lobu Tua Sejarah Awal Barus \\
\hline 11 & 2007 & Gusti Asnan & Dunia Maritim Pantai Barat Sumatera \\
\hline 12 & 2008 & Adrian B. Lapian & Pelayaran dan Perniagaan Nusantara Abad Ke-16 dan 17 \\
\hline 13 & 2010 & Daniel Perret & Kolonialisme dan Etnisitas Batak Dan Melayu di Sumatra Timur Laut \\
\hline 14 & 2011 & Anthony Reid & Menuju Sejarah Sumatra \\
\hline 15 & 2013 & William Masrden & (Edisi Terjemahan) Sejarah Sumatra \\
\hline 16 & 2013 & 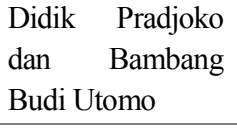 & Atlas Pelabuhan-Pelabuhan Bersejarah Di Indonesia \\
\hline 17 & 2015 & Daniel Perret, dkk & Barus Negeri Kamper Sejarah Abd ke-12 Hingga Pertengahan Abad ke-17 \\
\hline 18 & 2016 & $\begin{array}{l}\text { M.A.P. Meilink - } \\
\text { Roelofsz }\end{array}$ & Persaingan Eropa \& Asia di Nusantara -Sejarah Perniagaan 1500-1630- \\
\hline 19 & 2016 & Tome Pires & (Edisi Terjemahan) Suma Oriental \\
\hline
\end{tabular}

Tabel 1. Daftar Literatur terkait Kapur Barus dan Kemenyan

\section{PERDAGANGAN KAPUR BARUS DAN KEMENYAN DI SUMATERA UTARA SAAT INI}

Meski dalam jumlah yang sangat sedikit, saat ini pohon kapur barus masih dapat ditemukan antara lain di hutan-hutan di Kabupaten Tapanuli Tengah, Kabupaten Humbang Hasundutan dan Kabupaten Aceh Singkil. Status keberadaan pohon ka- pur barus di habitat alaminya sekarang dalam kondisi yang sangat kritis karena telah langka dan cukup sulit untuk ditemukan. Saat ini beberapa petani dari Kecamatan Sirondorung dan Kecamatan Manduamas sudah melakukan upaya pembudidayaan bibit kapur barus dalam skala kecil dan dengan cara yang sederhana. Bibit-bibit berusia 2 tahun kemudian ditanam di kebun-kebun mereka atau untuk dijual kepada masyarakat umum yang berminat 
atau memesan. Dari informasi yang didapat dari petani pembudidaya pohon kapur barus di Kec. Manduamas menyebutkan bahwa biasanya hanya $20 \%$ dari jumlah bibit kapur barus yang disemai yang akan berhasil hidup sampai dewasa. Oleh sebab itu, bibit pohon kapur barus usia 2 tahun dijual dengan harga Rp. 50.000 - Rp. 100.000 per bibit.

Bagian dari pohon kapur barus yang sampai saat ini masih diperjualbelikan adalah bagian batang pohon yang dipergunakan sebagai papan untuk bahan bangunan atau pun pembuatan kapal. Kayu dari pohon kapur barus dihargai dengan harga yang cukup tinggi di pasaran dibandingkan dengan kayu papan dari jenis pohon lain sebab kayu pohon kapur barus memiliki kualitas yang sangat baik. Oleh sebab itu biasanya petani pohon kapur barus akan menebang pohon mereka ketika mencapai usia lebih dari 10 tahun. Selain itu bagian kapur barus lainnya yang masih dapat ditemukan di pasar meski sangat langka adalah minyak kapur barus atau yang dikenal dengan minyak umbil. Minyal umbil dihasilkan dari getah pohon kapur barus yang dapat digunakan sebagai obat. Menurut pengakuan salah seorang petani kapur barus dari Desa Siordang,
Kec. Sirondorung, satu pohon kapur berusia puluhan tahun dapat menghasilkan minyak umbil sekitar 7 - 9 liter yang harganya jualnya cukup mahal. Sedangkan bagian dari kristal kapur barus yang berada dalam inti batang pohon kapur saat ini sudah tidak jual lagi. Kristal kapur barus yang sejak berpuluh abad silam hingga sampai pertengah abad ke-20 M masih menjadi komoditi primadona oleh para pedagang asing saat ini sudah tidak pernah ditemukan lagi. Salah seorang petani kapur barus dari Desa Siordang menyebutkan bahwa menurut sepengetahuannya penjualan kristal kapur barus ke Medan terakhir kali dilakukan pada tahun 1970-an.

Untuk pohon kemenyan keberadaanya tidak selangka pohon kapur barus karena di beberapa kabupaten di Provinsi Sumatera Utara masih terdapat hutan kemenyan yang merupakan hutan adat masyarakat Batak. Pohon kemenyan masih dapat ditemukan di Kabupaten Dairi, Kabupaten Tapanuli Utara, Kabupaten Pakpak Bharat, dan Kabupaten Humbang Hasundutan. Di Kabupaten Humbang Hasundutan sendiri, menurut data dari BPS Kab. Humbang Hasundutan (2009) tanaman kemenyan tersebar di 7 kecamatan.

\begin{tabular}{llrr}
\hline \multirow{2}{*}{ No } & Nama Kecamatan & \multicolumn{2}{c}{ Tanaman Kemenyan } \\
\cline { 3 - 4 } & & Luas (ha) & Produksi (ton) \\
\hline 1 & Pakkat & 57,00 & 16,53 \\
\hline 2 & Onan Ganjang & $1.039,00$ & 294,25 \\
\hline 3 & Sijamapolang & 592,00 & 125,25 \\
\hline 4 & Lintong Nituha & 0,00 & 0,00 \\
\hline 5 & Paranginan & 0,00 & 0,00 \\
\hline 6 & Dolok Sanggul & $1.405,50$ & 416,99 \\
\hline 7 & Pollung & 284,00 & 84,21 \\
\hline 8 & Parlilitan & 818,50 & 357,09 \\
\hline 9 & Tarabintang & 27,00 & 10,50 \\
\hline 10 & Baktiraja & 0,00 & 0,00 \\
\hline & Total & $4.221,00$ & $1.304,82$ \\
\hline
\end{tabular}

Tabel 2. Produksi Kemenyan di Kabupaten Humbang Hasundutan (Sumber: BPS Kabupaten Humbang Hasundutan, 2009) 


\section{Gambar 1: a) Pohon kapur barus yang ada di Kecamatan Manduamas, b) Potongan kayu pohon kapur barus di Desa Siordang, c) Minyak umbil yang disimpan oleh Bapak Silaban di Desa Siordang, dan d) Kristal kapur barus yang masih disimpan oleh mantan pencari kapur barus di Kecamatan Sirondorung}

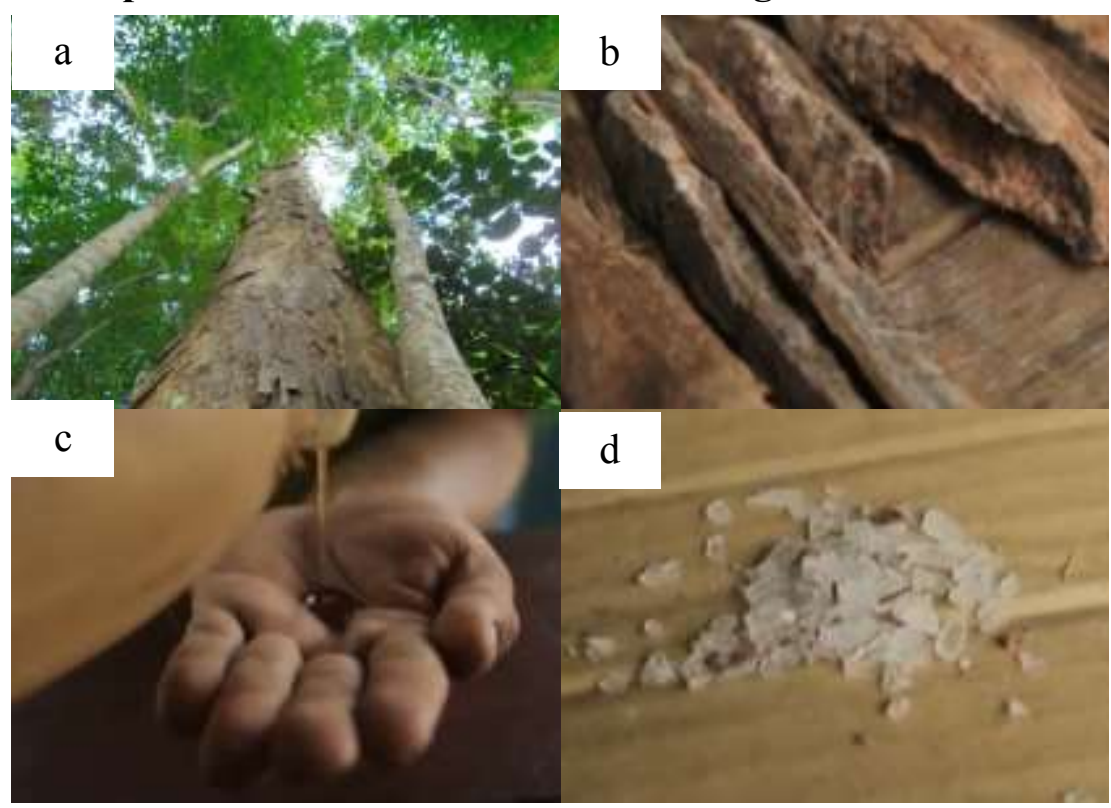

Bagi masyarakat Batak Toba, jenis kemenyan terbaik disebut hamijon toba, sedangkan jenis yang kurang baik disebut hamijon dairi atau hamijon durame (Katz, 2002:239). Hamijon toba memiliki harga lebih mahal sebab getah kemenyan yang diambil dari getah yang masih menempel di kulit pohon, sedangkan hamijon durame berharga lebih murah karena getah kemenyan diambil dari getah yang telah menetes di tanah sehingga kualitasnya kurang baik. Secara umum terdapat tiga jenis kemenyan yang dijual di pasaran yaitu kemenyan hitam, kemenyan merah, dan kemenyan putih. Kemenyan dari Sumatera Utara sebagian besar didistribusikan ke Pulau Jawa sebagai bahan rokok, dupa, dan parfum. Harga kemenyan berubah-ubah tergantung musim. Berdasarkan data yang didapat dari http://www.medanbisnisdaily.com menyebutkan pada bulan Maret 2016 harga kemenyan di Kabupaten Pak- pak Bharat mencapai Rp. 230.000/kg. Semakin lama getah kemenyan dikeringkan maka harganya pun akan semakin mahal.

\section{PENUTUP}

Penyebutan kapur barus dan kemenyan pada sumber-sumber asing di atas menunjukkan bahwa kedua komoditi ini merupakan bahan dagangan yang penting dan banyak dicari dari masa ke masa. Barus merupakan salah satu magnet sejarah perdagangan dunia. Tapi kenapa Barus yang sudah dicatat dalam sumber-sumber sejarah dunia itu tidak masuk dalam sejarah nasional Indonesia sehingga tidak masuk dalam pelajaran sejarah di sekolah sekolah?

Di sini yang terjadi bukanlah defenisi dan kategori "sejarah nasional" dan "sejarah lokal" dan revisi mana yang harusnya dibalik dari dua kategori itu. Yang berlangsung adalah "politik 
historiografi" dalam arti "kekuasaan" lah yang lebih menentukan arah penulisan historiografi dan pembelajarannya dan kebenaran sejarah. Kekuasaan yang menentukan arah penulisan historiografi itu juga bisa terjadi tanpa arah. Kunjungan tiba-tiba Presiden Jokowi bulan Maret 2017 ke Barus, meresmikan Titik Nol Peradaban Islam Nusantara di Barus, merupakan bagian dari "politik historiografi" yang tanpa arah, yang menguatkan pendapat bahwa kepentingan politik lah yang banyak bermain di pentas historiografi Indonesia dan pembelajarannya di sekolah.

Barus sendiri bukanlah tempat masuknya agama Islam pertama di Indonesia, dan penabalan Kilometer Nol Islam di Barus telah mendapat protes dan penolakan dari akademisi, ulama dan masyarakat Aceh. Presiden Jokowi oleh cendekiawan Aceh bahkan dianggap telah menistakan sejarah masuknya Islam di Indonesia. Jokowi dapat dimaklumi jika tidak begitu faham sejarah Indonesia. Tapi kenapa dia berani menabalkan Barus sebagai Kilometer Nol Sejarah Islam dan berpidato seperti "sejarahwan Islam" dan menyebut sejak zaman Nabi Muhammad Islam sudah masuk ke Barus? Untuk menjawabnya kita harus melakukan pertanyaan politik dan harus faham dinamik apa yang ada di belakang acara "politik sejarah" Jokowi ke Barus itu. Uraian ini tidak membahasnya sampai ke situ.

Akan tetapi jika arus "politik sejarah nol Kilometer Barus" lewat Jokowi terus berjalan tanpa penentangan, maka akan muncul episode baru : Barus menjadi Sejarah Nasional masuknya Islam ke Indonesia. Barus yang disebut dalam narasi sejarah perdagangan dunia dunia bergeser ke sejarah lokal karena politik historiografi tak memperdulikannya, lalu di bawah presiden Jokowi, lewat arus politik historiografi di sekitar istana, bergeser lagi ke sejarah nasional berbasis sejarah masuknya Islam pertama di Indonesia. Tanpa data sejarah yang benar pula. Padahal Barus dengan dua komoditi utamanya (kemenyan dan kampher/kapur) sudah menjadi ikon sejarah perdagangan dunia sebelum agama Islam ada.

Oleh karena itu di tengah tengah arus "politik historiografi" kita perlu memperkuat para pendidik sejarah kita untuk menyusun strategi bagaimana mengajarkan sejarah kritis kepada anak didik dan mencari cara bagaimana mengajarkan bahwa narasi sejarah itu berubah ubah dari masa ke masa. Apa yang dijarkan dalam sejarah bisa berubah jika ada temuan temuan baru, sudut pandang baru dan arah politik baru.

\section{DAFTAR RUJUKAN}

Ambary, H.M. 1998. Menemukan Jejak Historis Dan Arkeologis Islam Indonesia. Jakarta: Logos Wacana Ilmu.

Asnan, G. 2007. Dunia Maritim Pantai Barat Sumatera. Yogyakarta: Ombak.

Cortesao, A. 2016. Suma Oriental Karya Tome Pires: Perjalanan dari Laut Merah Ke Cina \& Buku Francisco Rodrigues. Yogyakarta : Ombak.

Guillot, C. (ed). 2002. Lobu Tua Sejarah Awal Barus. Jakarta: Yayasan Obor Indonesia.

Katz, E. 2002. Pengelolahan Kemenyan Di Dataran Tinggi Batak: Keadaan Sekarang, dalam Guillot, C. (ed), Lobu Tua Sejarah Awal Barus. Jakarta: Yayasan Obor Indonesia.

Kévonian, K. 2002. Suatu Catatan Perjalan Di Laut Cina Dalam Bahasa 
Armenia, dalam Guillot, C. (ed), Lobu Tua Sejarah Awal Barus. Jakarta: Yayasan Obor Indonesia.

Masden, W. 2013. Sejarah Suamtra. Jakarta : Komunitas Bambu.

McKinnon, E. E.. 2011. Ancient Fansur, Aceh's Atlantis'? The case for Lhok Pancu / Indrapurwa". Solo: IAHA.

Perret, D., dkk. 2008. Barus Seribu Tahun Yang Lalu. Jakarta: Kepustakaan Populer Gramedia.

Perret, D. 2010. Kolonialisme dan Etnisitas Batak dan Melayu Di Sumatera Timur Laut. Jakarta: Kepustakaan Populer Gramedia.

Perret, D, dan Surachman, H (Peny). 2015. Barus Negeri Kamper: Sejarah Abad Ke-12 hingga Pertengahan Abad ke-17. Jakarta:Kepustakaan Populer Gramedia.

Pradjoko, D. dan Utomo, B.U. 2013. Atlas Pelabuhan Bersejarah di Indonesia. Jakarta:Direktorat Jenderal Kebudayaan.

Ptak, R. 2002. Kumpulan Rujukan Cina yang Mungkin Berkaitan Dengan Daerah Barus (dari Dinasti Tang Sampai Ming), dalam Guillot, C.(ed), Lobu Tua Sejarah Awal Barus. Jakarta:Yayasan Obor Indonesia.

Sitompul, M. 2011. Kajian Hutan Kemenyan (Styrax sp.) Di Kabupaten Humbang Hasunndutan, Provinsi Sumatera Utara. Bogor: Institut Pertanian Bogor (Disertasi).

Stéphan, N. 2002. Kamper dalam Sumber Arab dan Persia Produksi dan
Penggunaannya, dalam Guillot, C. (ed), Lobu Tua Sejarah Awal Barus. Jakarta: Yayasan Obor Indonesia.

Subbrayalu, Y. 2002. Prasasti Perkumpulan Pedagang Tamil Di Barus Suatu Peninjauan Kembali, dalam Claude Guillot (ed), Lobu Tua Sejarah Awal Barus. Jakarta: Yayasan Obor Indonesia.

Sumber Internet :

http://www.medanbisnisdaily.com

http://lesserknowntimberspecies.com 